\title{
“VAI CHATEAR O CAMÕES": A CONSTRUÇÃO IMPOSITIVA DE DESTRATO
}

\author{
“GO BOTHER CAMÕES": \\ THE IMPOSITIVE CONSTRUCTION OF MISTREATING
}

José Romerito Silva | Lattes | jromeritosilva@hotmail.com
Universidade Federal do Rio Grande do Norte

Maria Aparecida da Silva Andrade | Lattes | aparecida.silvand@hotmail.com Instituto de Educação Superior Presidente Kennedy

Resumo: Neste trabalho, temos como objeto de estudo a construção impositiva de destrato com o verbo ir, aqui denominada CID. Essa construção representa um ato de fala diretivo e está associada a um momento de desacordo entre os parceiros de interação, em que o locutor, irritado, insulta o interlocutor, repelindo-o. Tomamos, como referencial teórico a Linguística Funcional Centrada no Uso (LFCU) e contribuições da Gramática de Construções. Adicionalmente, recorremos aos estudos em Pragmática, em particular, às noções de polidez e de face. $\mathrm{O}$ estudo é de natureza qualitativo-interpretativa, para o qual utilizamos como material de análise textos de gêneros diversos tanto de fala quanto de escrita.

Palavras-chave: Construção de destrato. Imperativo. Verbo ir. Linguística Funcional Centrada no Uso. Gramática de Construções.

Abstract: In this paper, the object of studying is the imperative construction of mistreating with the verb to go, named here CID. That construction represents a directive speech act and it is related to a situation of disagreement between the speaker/writer and his interlocutor. In this case, the speaker/writer shows to be irritated and insult his addressee. The study is based on Usage-based Functional Linguistics and on contributions from Construction Grammar. Besides, we use contributions from Pragmatics, specially the notions of politeness and face. Here we adopt the qualitative and interpretative methods of analysis and the database is collected from spoken and written texts of different genres.

Keywords: Construction of mistreating. Imperative. Verb to go. Usage-based Functional Linguistics. Construction Grammar. 


\section{Introdução}

O imperativo tem sido alvo de diversos estudos, em particular, no âmbito da Linguística. Entre eles, citamos, por exemplo, o de Sampaio (2001), que estuda a expressão do imperativo no português contemporâneo; o de Cardoso (2006), que trata do uso do imperativo em estratégias de negação; o de Scherre (2007), que abordam aspectos morfológicos e sintáticos do imperativo em perspectiva variacionista; o de Rumeu (2016), que examina variações do imperativo nos séculos XIX e XX; e o de Oliveira (2017), que investiga o imperativo no nordeste brasileiro em viés sociolinguista.

O verbo ir, por sua vez, também já recebeu atenção em diversos trabalhos, especialmente no que se refere a seus usos gramaticais. Entre esses trabalhos, temos, por exemplo, os de Gonçalves (2012) e Móia (2017), tratando da gramaticalização desse verbo como auxiliar de tempo futuro; os de Wiedemer (2008) e Pinheiro (2014), examinando-o como verbo regencial de movimento; o de Oliveira (2009), analisando a polifuncionalidade desse verbo. Existem, ainda, outros estudos abordando questões léxico-gramaticais variadas relativas ao verbo $i r$, entre eles, Longhin-Thomazi (2010) e Andrade (2017).

$\mathrm{Na}$ abordagem dos gramáticos - tradicionais ou linguistas - sobre o imperativo, este é, em geral, apresentado como designativo de ordem ou pedido. No que se refere ao verbo ir, o tratamento dado por eles limita-se a descrevê-lo como auxiliar.

Considerando mais especificamente o uso de expressão imperativa para demonstrar irritação do falante/escrevente e rejeição a seu interlocutor, na coleta de dados realizada, ao menos dentro do nosso alcance de investigação, nada foi possível encontrar, nem em relação a expressões gerais desse tipo tampouco particularmente com o verbo ir. Assim, em vista da existência, no português, de expressões do tipo Vá plantar batatas!, Vai te danar! e da aparente lacuna de estudos específicos sobre esse fenômeno discursivo, neste trabalho, abordamos a construção impositiva com o verbo ir como recurso (inter) subjetivo marcador de irritação do locutor e de destrato/repulsa a seu interlocutor (doravante, construção impositiva de destrato, ou CID) no português contemporâneo ${ }^{1}$. Essa construção pode ser associada à construção de ordem literal e direta, com a qual estabelece certo paralelismo formal, sendo ambas instanciações da construção (mais geral) de comando.

Para tanto, valemo-nos do aparato teórico-metodológico da Linguística Funcional Centrada no Uso, tal como se apresenta em Furtado da Cunha, Bispo e Silva (2013), Oliveira e Rosário (2015), e da Gramática de Construções, conforme traçada em

\footnotetext{
${ }^{1}$ Optamos pelo termo "impositiva" por ser mais geral, uma vez que a construção impositiva pode ser codificada por outras formas verbais além do imperativo.
} 
Goldberg (1995), Croft (2001), Fried (2015) e outros. Nesse viés, além das noções gerais sobre construção, recorremos a conceitos operacionais como analogização, chunking, iconicidade e marcação. Como ferramenta auxiliar de análise, apoiamo-nos, ainda, em estudos no âmbito da Pragmática, especialmente nas noções de ato de fala, nos termos de Austin (1990) e de Searle (1984); de inferência pragmática, apresentada em Traugott e Dasher (2002), Bybee (2010); de face e de polidez, conforme entendidas em autores como Leech (1983), Lakoff (1989), Culpeper (2012), Barrere (2017).

Como objetivos, temos: (1) descrever os padrões construcionais da CID no que se refere, principalmente, a seus aspectos sintáticos e morfológicos; (2) analisar a CID em termos de seus graus de esquematicidade, produtividade e composicionalidade; (3) examinar a CID quanto a fatores semânticos, discursivos e pragmáticos envolvidos em seu uso.

Quanto à metodologia, nossa abordagem é de natureza qualitativo-interpretativa, em perspectiva sincrônica. $\mathrm{O}$ material de análise provém de fontes textuais diversificadas, mormente da web, contemplando amostras de fala e de escrita do português atual. Não optamos por um corpus específico e fechado em razão do risco de não obtermos uma amostra expressiva de dados - o que poderia limitar e comprometer a análise -, embora o controle da frequência de tokens (ocorrências) não seja alvo de nossa atenção neste estudo.

Este trabalho está dividido em quatro tópicos principais: neste primeiro - introdutório -, apresentamos um panorama geral do estudo aqui realizado; no segundo, fazemos uma breve explanação do quadro teórico que dá suporte à nossa análise; no terceiro, procedemos ao exame de nosso objeto de investigação; no quarto - último -, tecemos as considerações finais em torno do que foi examinado.

\section{Moldura teórico-metodológica}

Linguística Funcional Centrada no Uso (LFCU), denominação cunhada no Brasil pelo grupo de estudos linguísticos Discurso \& Gramática, refere-se a uma nova tendência de abordagem que conjuga pressupostos teórico-metodológicos da tradição funcionalista norte-americana - segundo pesquisadores como Talmy Givón, Sandra Thompson, Paul Hopper, Joan Bybee, Elizabeth Traugott - e contribuições da Gramática de Construções (GC) conforme formuladas por Adele Goldberg, William Croft, Ronald Langacker, Mirjam Fried, Thomas Hoffmann, entre outros (BYBEE, 2010; SILVA, 2019). Esse 
modelo corresponde ao que Kemmer e Barlow (2002), Beckner et al. (2009), Diessel (2017), entre outros chamam Usage-based Approach (Abordagem Centrada no Uso).

No contexto brasileiro, em particular, a LFCU tem aberto um amplo leque de pesquisas, tanto em perspectiva sincrônica quanto diacrônica. Entre os trabalhos representativos dessa nova vertente estão, por exemplo, Cezario e Furtado da Cunha (2013), Oliveira e Rosário (2015), Oliveira e Cezario (2017), Furtado da Cunha, Bispo e Silva (2018), Wiedemer e Oliveira (2019), nos quais se adota, principalmente, a abordagem construcional da língua.

Entre os postulados básicos da LFCU, estão a ideia de que a língua, em seu conjunto multifacetado de formas e funções (ou construções), emerge, regulariza-se, varia e se modifica a partir das experiências discursivas de seus usuários na comunicação cotidiana, no que também contribuem fatores de natureza cognitiva; léxico e gramática constituem um continuum gradiente, não havendo nenhum componente central em relação aos demais; a língua deve ser compreendida em referência ao uso que dela se faz (KEMMER; BARLOW, 2002; FORD; FOX; THOMPSON, 2003).

Gramática de Construções, por sua vez, diz respeito a uma corrente dos estudos linguísticos de base cognitivista. Parte do pressuposto central de que a língua é um inventário estruturado de construções - pareamentos de forma e função (semântica e/ou pragmática) -, adquiridas a partir da combinação do input (uso) com mecanismos cognitivos gerais. Sendo assim, toma a construção como a unidade básica da língua (GOLDBERG, 1995; 2003).

Para a GC, as construções de uma língua consistem em uma rede taxonômica hierarquizada cujos nós se acham interligados por links de herança e de relações diversos (GOLDBERG, 1995). Conforme Östman e Fried (2005), a construção consiste no par forma-função, a qual pode ser instanciada por um morfema (-Suf), uma palavra (Adj), um sintagma (SP), uma expressão idiomática (Pau pra toda obra), uma sentença (Suj Pred), um período (Oração subordinante e Oração subordinada) ou mesmo um texto (Slogan). Segundo Croft (2001), o elo simbólico constitutivo da construção une uma forma, composta por propriedades fonológica, morfológica e sintática, a uma função, que inclui as propriedades semântica, discursiva e pragmática. O quadro a seguir ilustra essa natureza simbólica da construção, em relativa similaridade ao que se encontra em Croft (2001) e em Traugott e Trousdale (2013). 
Quadro 1 - Constituição simbólica da construção.

\begin{tabular}{|c|c|c|}
\hline \multicolumn{2}{|c|}{ C O N S T R U Ç Ã O } \\
\hline Forma & \multirow{2}{*}{ Elo simbólico } & Função \\
\cline { 1 - 1 } $\begin{array}{c}\text { Propriedades morfossintáticas } \\
\text { e fonético-fonológicas }\end{array}$ & & $\begin{array}{c}\text { Propriedades semânticas e } \\
\text { discursivo-pragmáticas }\end{array}$ \\
\hline
\end{tabular}

Fonte: Adaptado de Croft (2001).

De acordo com Fried (2015), uma construção pode ser: totalmente aberta/não especificada, a exemplo da sequência Det $N$ Mod, cujos slots podem ser preenchidos por elementos diversos; parcialmente especificada, como é o caso de $X$ tão Y que Z; totalmente especificada e parcialmente variável, tal como a expressão Ficar de queixo caído, em que o primeiro componente (o verbo ficar) se flexiona em tempo-modo e número-pessoa; totalmente especificada e invariável, como, por exemplo, o adjetivo simples, a expressão pé de chinelo ou o ditado popular Seguro morreu de velho.

$\mathrm{Na}$ esteira dessa ideia, defende-se que as construções possuem propriedades variadas e graduais em termos de esquematicidade, de produtividade e de composicionalidade (TRAUGOTT; TROUSDALE, 2013). Segundo essa ótica, uma construção pode ser -/+esquemática, -/+produtiva, -/+composicional; também pode ser completamente idiossincrática e não analisável.

A esquematicidade refere-se aos graus de generalidade, abstração e (in)especificidade da construção. Por exemplo, a construção oracional SN SV é altamente geral, esquemática, abstrata e não específica. A produtividade, relacionada à extensibilidade construcional, tem a ver com as condições que uma construção tem de licenciar uma certa quantidade de construções a ela vinculadas. Um exemplo disso é a possibilidade que a construção $S N S V$ tem de inseminar um leque amplo e variado de construções, tais como a intransitiva, a transitiva, a ditransitiva, entre outras. A composicionalidade relaciona-se ao grau de transparência e correlação entre o plano da forma e o do significado de uma construção bem como ao grau de analisabilidade de seus componentes. Exemplos dessa propriedade são as construções dar um presente a alguém (+composicional), que designa uma ação volitiva e controlada de transferência de um objeto material a um recipiente beneficiário, e dar preocupação a alguém (-composicional), em que não há paridade entre forma 
e significado, pois a locução dar preocupação forma um todo semântico (= preocupar); ademais, não conceitualiza transferência intencional de um objeto físico tampouco o recipiente é, de fato, beneficiário.

A noção de esquematicidade é importante para se aferir, por um lado, até que ponto uma construção é hierarquicamente mais geral em relação a outra(s) e, por outro, em que medida ela sanciona (sub)types diversos de construções (frequência de type, segundo BYBEE, 2010), identificando-se, com isso, sua produtividade. Nesse viés, Traugott e Trousdale (2013) distinguem esquema, subesquema, microconstrução e construto. $O$ esquema é superordenado, geral, abstrato e inespecífico. O subesquema é uma instanciação do esquema ao qual é hierarquicamente subordenado, sendo mais especificado do que este. ${ }^{2}$ A microconstrução constitui uma instanciação do subesquema, representando um exemplar ainda mais especificado deste. O construto é a realização efetiva (token), ou uso, de uma (micro) construção em uma dada situação real de fala ou de escrita. O quadro a seguir exemplifica essa relação em rede (cf. CROFT, 2001; TRAUGOTT; TROUSDALE, 2013).

Quadro 2 - Rede esquemática de uma construção.

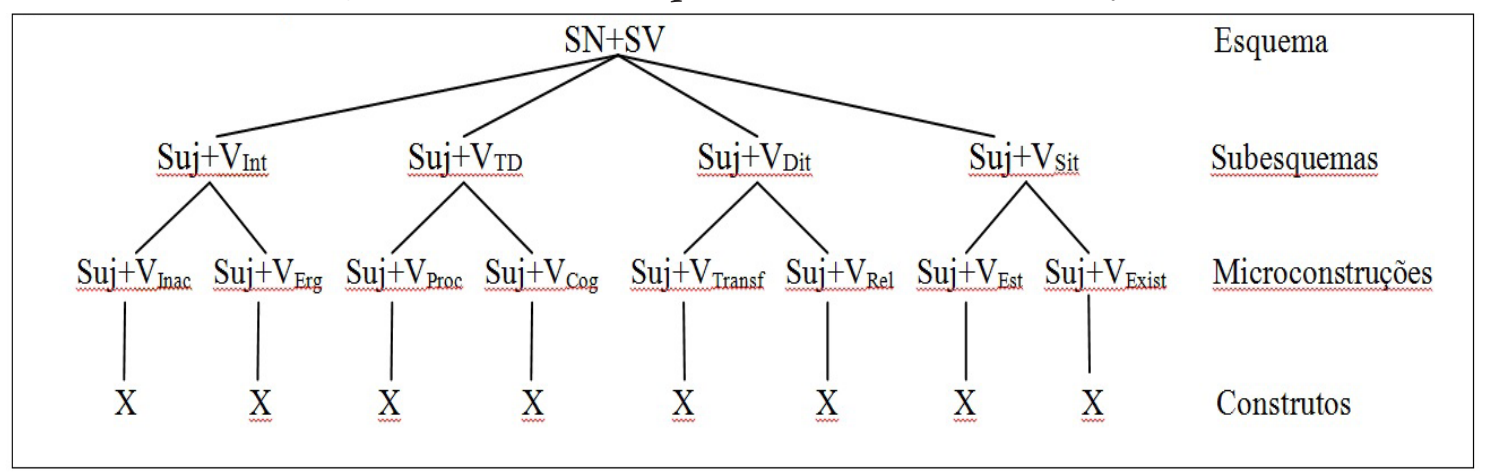

Fonte: Autoria própria, com base em Traugott e Trousdale (2013).

Tratando dos links (elos) entre construções, Goldberg (1995) postula haver links relacionais e links de herança. Os primeiros dividem-se em quatro tipos: polissemia, metáfora, subparte e instanciação. O de polissemia tem a ver com o fato de uma dada construção apresentar o mesmo template formal de outra, mas diferir relativamente desta em

\footnotetext{
${ }^{2}$ Cabe assinalar que um subesquema pode também ser produtivo a ponto de licenciar subesquemas de nível inferior, sendo estes mais especificados (i.e., menos esquemáticos/relativamente especificados) do que aquele, os quais podem ser instanciados por microconstruções diversas (TRAUGOTT; TROUSDALE 2013). Um exemplo disso é a construção estativa $\mathrm{SN}_{\text {Suj }} \mathrm{V}_{\mathrm{Est}} \mathrm{X}_{\text {Predict }}$ que é subesquemática em relação ao esquema SN SV e pode ser instanciada por subesquemas mais especificados, como SN V SN, SN V SA, SN V SAdv ou SN V SP.
} 
termos semânticos. Um exemplo disso é a construção transitiva Eu esqueci a carta $\left(\operatorname{Suj}_{\mathrm{Exp}}\right.$ $\left.\mathrm{V}_{\mathrm{Cog}} \mathrm{Obj}_{\text {Tema }}\right)$, que se associa esquematicamente à sua "co-irmã” mais prototípica Eu rasguei a carta ( $\left.\mathrm{Suj}_{\mathrm{Ag}} \mathrm{V}_{\mathrm{Ação}} \mathrm{Obj}_{\mathrm{Pac}}\right)$, mas não possui a mesma correspondência quanto aos papéis temáticos dos componentes. $\mathrm{O}$ de metáfora revela extensão de sentido em um ou mais componentes de uma construção. Em Ela entrou em depressão, por exemplo, entrar é conceptualizado metaforicamente como movimento para dentro e depressão como local. O de subparte se estabelece quando uma construção exibe uma configuração parcial de outra, mas tem existência própria. Isso pode ser exemplificado com $A$ porta abriu, que é parte da construção Alguém/Algo abriu a porta. O de instanciação se mostra no fato de uma construção constituir-se como um caso ad hoc de outra. Por exemplo, uma construção intransitiva pode, eventualmente, apresentar-se como sintaticamente "transitiva", conforme se vê em Eu chorei essa perda (SN1 V SN2).

Os links de herança referem-se às inter-relações de construções na rede, no sentido de que uma construção herda propriedades de outra, que é superordenada e mais geral (esquemática). Desse modo, um nó na rede herda propriedades de seu(s) nó(s) dominante(s). Um construto como O bebê sorriu, por exemplo, herda propriedades da construção intransitiva, que, por seu turno, herda propriedades da construção mais esquemática $\mathrm{SN}_{\text {Suj }} \mathrm{SV}_{\text {Pred }}$. Nessa ótica, uma construção pode, ainda, herdar propriedades de mais de uma construção, o que Goldberg (1995) chama de "link de herança múltipla". Um exemplo disso é o construto Por que o trabalho não foi feito?, o qual herda, ao mesmo tempo, propriedades das construções interrogativa, negativa e passiva.

Sob o abrigo dessa abordagem cognitivo-funcional da língua, valemo-nos, em nossa análise, das noções de chunking, analogização, iconicidade e marcação. Estas são brevemente explicitadas a seguir.

Chunking, de acordo com Bybee (2010), refere-se a uma cadeia de itens linguísticos que coocorrem em um dado contexto de uso. Pela repetição frequente, esses itens podem passar a ser vistos integradamente, de modo a compor um todo formal e semântico convencionalizado, isto é, um chunk. O chunk é, portanto, um tipo de construção estocada na memória dos falantes a partir de experiências discursivas recorrentes. Sob essa ótica, um SP, por exemplo, pode ser considerado um chunk, visto ser composto por termos que sempre coocorrem - Prep $X$ - formando um todo significativo. Para tanto, colaboram habilidades cognitivas de domínio geral, tais como categorização, percepção de relações de contiguidade e inferenciação. 
Segundo Traugott e Trousdale (2013), analogização - ancorada no processo cognitivo de comparação e associada ao processo de mudança linguística - diz respeito ao mecanismo por meio do qual uma construção é utilizada de modo inovador (na verdade, um novo construto) com base na similaridade de forma e/ou de conteúdo com uma construção mais já existente. Nesse caso, um dado pareamento forma-função é tomado em termos de outro, considerando-se relativo(s) paralelismo(s) entre ambos (cf. TRAUGOTT; DASHER, 2002; BYBEE, 2010). Assim é que a expressão um bocado de preocupação (não contável abstrato), por exemplo, formula-se via analogização a partir de expressões quantitativas como um bocado de gente (contável concreto).

O princípio de iconicidade tem a ver com a correlação transparente entre forma e significado (HAIMAN, 1985; GIVÓN, 1995; BYBEE, 2012). Essa correlação é cognitivamente motivada, posto que facilita o processamento conceitual do conteúdo. Nesse sentido, quanto mais expressiva e/ou mais literal for a correspondência entre a estrutura linguística e seu designatum, mais icônica é a construção. Inversamente, quanto menor for essa correspondência, menos icônica é a construção. Nesse viés, conforme Beck (2000), uma construção de conteúdo mais abstrato/metaforizado e/ou de expressividade mais econômica, que demanda maior esforço cognitivo de processamento, tem baixo grau de iconicidade ou pode até mesmo ser não icônica.

Posta nesses termos, iconicidade pode ser vinculada à noção de marcação (GIVÓN, 1995). Esta, por sua vez, se refere a traços distintivos entre uma expressão linguística e outra com a qual está em relação de contraste (BYBEE, 2012). Entre os critérios definidores da marcação estão o grau de (im)previsibilidade contextual, o grau de complexidade cognitiva e/ou estrutural, o grau de transparência entre forma e conteúdo e o grau de frequência de uso da expressão (BECK, 2000). Desse modo, uma construção pode ser considerada menos ou mais marcada. ${ }^{3}$ Como exemplo da relação entre iconicidade e marcação, podem ser citadas a ordem normal Pegue o dinheiro e a ordem de expulsão Pegue o beco. No primeiro caso (Pegue o dinheiro), há maior transparência entre forma e significado, pois se trata de uma ordem literal, sendo de uso mais comum; portanto pode ser considerada menos marcada. Já no segundo caso, Pegue o beco equivale a Sai(a) daqui/Vá embora; logo é uma expressão não literal, em que não há correspondência entre expressão e conteúdo, sendo de uso pouco comum por se restringir a certos contextos de interlocução, daí ser mais marcada.

\footnotetext{
${ }^{3}$ Não é matéria de interesse aqui o detalhamento dos princípios de iconicidade e marcação tampouco as questões em torno deles. Para tanto, remetemos a Givón (1995), Beck (2000), Haspelmath (2008), Bybee (2012).
} 
Considerando a dimensão funcional (i.e., semântica, discursiva e pragmática) da construção, no continuum léxico-gramática, há construções que se associam mais à referencialidade de um evento ou de um estado de coisas, no sentido de revelarem conteúdo mais voltado para relatar/ descrever a realidade objetiva ou subjetiva. ${ }^{4}$ Outras construções, entretanto, têm caráter performativo (intersubjetivo), estando mais vinculadas à interação comunicativa em si, isto é, à relação entre os sujeitos de discurso (TOMASELLO, 1998). Nessa última categoria, incluem-se, por exemplo, construções que representam vocativos, saudações, despedidas, bênçãos. Também fazem parte dessa categoria as construções que instanciam atos de fala diretivos. Tais construções sinalizam, além de significados relativos ao relacionamento entre falante/ouvinte ou escrevente/ leitor, aqueles que deixam implícitos graus de (as)simetria social e de afetividade entre esses parceiros de interlocução (CULPEPER, 2012; HORN; KECSKES, 2013).

Em se tratando da relação entre locutor e interlocutor, trazemos, ainda, para este trabalho algumas noções fundamentais nos estudos em Pragmática, a saber: ato de fala, inferência pragmática, face e polidez.

O conceito de ato de fala é primeiramente atribuído a Austin (1990), para quem, ao falarmos, realizamos uma ação por meio da língua(gem), ou seja, “dizer é fazer”. Os atos de fala, segundo esse autor, dividem-se em locucionário, que se refere ao fato de emitirmos verbalmente um enunciado; ilocucionário, que corresponde à própria ação realizada ao dizermos algo (afirmar, perguntar, pedir, ordenar, prometer, jurar etc.), isto é, sua força ilocucionária; perlocucionário, que se volta para o interlocutor, provocando neste uma dada reação (por exemplo, um convite requer do destinatário o aceite ou a recusa).

Para Searle (1984), um ato de fala pode ser direto/explícito ou indireto/implícito. É direto, (ou explícito), quando o locutor verbaliza expressamente a força ilocucionária do ato. Um exemplo disso é o caso de se dizer Estou lhe pedindo pra voltar. É indireto (ou implícito) quando o locutor "mascara" a força ilocucionária do ato. Por exemplo, se um acompanhante, ao ver o sinal de estacionamento proibido, diz para o motorista Olhe aí $a$ placa!, não está, com isso, fazendo um pedido ou dando uma ordem, mas alertando-o a não estacionar a fim de evitar a multa. ${ }^{5}$

Atrelada à ideia de ato de fala indireto/implícito, está a noção de inferência pragmática, ou "inferência convidada" ("invited inference"). Esta, segundo Traugott e Dasher (2002), diz respeito ao processo intersubjetivo em que o falante, ao utilizar uma dada ex-

\footnotetext{
${ }^{4}$ Não estamos, com isso, assumindo a ideia da relação/correspondência direta entre linguagem e mundo.

${ }^{5}$ Não cabe aqui nos atermos às discussões críticas em torno da Teoria dos Atos de Fala tal como formulada inicialmente por Austin e por Searle. Para tanto, ver, por exemplo, Souza Filho (2006).
} 
pressão linguística diferente do convencional, conta com a colaboração do ouvinte para que este apreenda (ou infira) o significado pretendido. Sob essa ótica, consiste na negociação de sentidos entre falante e ouvinte no curso da interação verbal (BYBEE, 2010; TRAUGOTT; TROUSDALE, 2013).

Inferência pragmática, ainda conforme esses autores, aproxima-se, relativamente, da noção griceana de implicatura; entretanto, não se limita tão somente ao princípio de cooperação entre os interlocutores para produção e compreensão de atos de fala indiretos/implícitos. Também se estende ao cálculo de sentido no caso em que o locutor recorre à extensão semântica e/ou à inovação morfossintática com um novo significado pragmático, cuja interpretação pelo ouvinte é favorecida por mecanismos cognitivos e fatores contextuais (BYBEE, 2010; HORN, 2012b).

A noção de face está diretamente relacionada à ideia de preservação da autoimagem pública nas situações interativas (GOFFMAN, 1980). Em outras palavras, ao interagirem, os indivíduos esforçam-se em apresentar imagens positivas de si próprios. Para Goffman, o locutor não apenas procura resguardar sua própria imagem (ação defensiva), mas também a de seu interlocutor (ação protetora).

Nessa perspectiva, a ideia de face associa-se à noção de polidez, que tem a ver com o conjunto de estratégias de comportamento linguístico por meio das quais os interlocutores regulam as imagens que constroem de si mesmos e do outro ao longo da interação (BROWN; LEVINSON, 1987). Essas estratégias se inscrevem em expressões que, em geral, indicam atitudes como colaboração, respeito, cortesia, além de outras que sinalizam, explicitamente ou não, o cuidado que os parceiros de interlocução têm de apresentar uma face positiva, especialmente em contextos nos quais podem ser alvo de censura social (OLIVEIRA, 2005).

Afastando-se relativamente do entendimento de Goffman e de Brown e Levinson sobre essas noções, pesquisadores como Leech (1983), Lakoff (1989), Reis (2009), Cunha e Silveira (2011), entre outros, concebem-nas em termos de um continuum que pode ser flagrado nas situações efetivas de interação verbal. Nesse sentido, a face pode estender-se gradientemente entre positiva e negativa; da mesma forma, a demonstração de (im)polidez pode ser gradiente (LEECH, 1983). Sendo assim, as estratégias de polidez podem se encaminhar para a manutenção da face positiva ou para desconstrução desta (CULPEPER, 2012; BARRERE, 2017). No primeiro caso, o(s) sujeito(s) de interlocução tende $(\mathrm{m})$, em maior ou menor grau, a expressar tratamento respeitoso; no segundo, revela $(m)$, disfarçada ou explicitamente, atitude de desprezo, chegando, em certas situa- 
ções, ao ataque verbal de maneira rude (CUNHA; SILVEIRA, 2011). É nesse segundo caso, pois, que situamos a construção aqui abordada.

\section{A construção impositiva de destrato - CID}

A construção de comando (CC) representa um leque variado de atos de fala ilocucionários de valor diretivo - nos termos de Searle (1984) -, entre os quais estão ordem, proibição, ameaça, instrução, pedido, sugestão, convite etc. Essa construção é instanciada por uma rede de construções subordenadas, que realizam tais atos de fala por meio de estruturas de codificação bastante diversas. Os atos ilocucionários realizados por essas construções associam-se, paralelamente, a atos de fala perlocucionários, posto que seu conteúdo se projeta diretamente sobre o ouvinte/leitor, visando, em maior ou menor grau de ingerência, determinar/orientar a ação deste (SOUZA FILHO, 2006). Sob esse prisma, a CC pode ser considerada um domínio funcional complexo, nos termos de Givón (1995). ${ }^{6}$

A construção impositiva (CI), constituindo-se como uma das instanciações da CC, sanciona um grupo de construções subesquemáticas com funções distintas. Entre elas, enquadra-se a CID com o verbo ir, foco central de nosso estudo. Apenas a título de amostragem, vejamos os recortes textuais que seguem:

1. Certifique-se de que o tipo de bateria é o recomendado para o seu veículo. Antes de remover a bateria usada, observe qual o seu terminal, se positivo (+) ou negativo (-), que está ligado ao cabo ou malha de aterramento ou massa. $\mathrm{O}$ cabo de aterramento é o que está ligado ao bloco do motor ou lataria. Marque qual é ele. Primeiro, desconecte e remova o cabo de aterramento. Em seguida, remova o cabo ligado ao sistema elétrico do veículo.

Link da amostra $1^{7}$

2. Abra suas asas

Solte suas feras

Caia na gandaia

Entre nessa festa

Link da amostra 2

\footnotetext{
${ }^{6}$ Domínio discursivo complexo, segundo Givón (1995), diz respeito a um amplo conjunto de propriedades semânticas e discursivo-pragmáticas relativamente similares, as quais podem ser codificadas por diferentes estruturas formais, no âmbito da (língua)gem.

${ }^{7}$ Nota da Edição: caso algum dos links esteja fora do ar, basta copiá-lo para o arquivador digital https:// web.archive.org/. Obs. links pouco acessados não são arquivados.
} 
3. Arrume suas coisas põe na mala

E deixe de uma vez a nossa casa

Vá embora...

Link da amostra 3

Nesses três recortes textuais, verificamos a voz de comando com o uso do imperativo. Entretanto, podemos perceber que, neles, embora se realizem atos de fala diretivos, há diferenças quanto ao grau de imposição do locutor sobre a ação do interlocutor. Em 1, o interlocutor é genérico - ou seja, qualquer pessoa que for instalar bateria em um veículo - e o comando é mais indireto e atenuado em razão de se tratar de um guia de instrução (Certifique-se, observe, marque, desconecte, remova). Em 2, o interlocutor também parece ser genérico, sendo também menor o grau de diretividade sobre sua ação, uma vez que o comando soa mais como uma sugestão (Abra, solte, caia, entre). Já em 3, o interlocutor é individuado - provavelmente, o cônjuge do locutor - e a voz deste é impositiva, isto é, exprime uma ordem (Arrume, põe, deixe, vá [embora]). Sendo assim, entendemos que tais recortes instanciam microconstruções diversas, pois, embora apresentem a mesma forma de imperativo (com variação morfológica apenas no caso de põe - em 3), exibem diferentes funções semântico-pragmáticas.

A CID, por sua vez, instancia igualmente um ato de fala diretivo, sendo configurada por subesquemas microconstrucionais estruturalmente distintos entre si. Contudo, ela diverge dos casos vistos nos exemplares de 1 a 3 pelo fato de adicionar à voz de "comando" a ideia de aborrecimento por parte do locutor em relação a seu parceiro de interação, a rejeição a este e a sinalização de encerramento do contato. Ademais, a irritação do falante/escrevente e a rejeição a seu interlocutor são marcadas, na maioria das vezes, por expressões imperativas não literais, sendo, em algumas situações, bastante ofensivas. Vejamos algumas amostras delas:

4. Agora, caifora

E sai da minha vida

De uma vez

Cai fora, vai embora

E leve tudo que

Você me fez 
5. Eles ainda não perceberam que até os russos e os chineses adoram o capitalismo e os americanos e continuam repetindo esse papo usando um IPhone... Vá plantar batatas, André Singer... Nem o nome ajuda... marca de máquina de costura! Vá costurar em outra freguesia!

\section{Link da amostra 5}

6. Mais de 2/3 da minha cabeça estariam livres pra pensar em outra coisa se não fosse você a infernizar a paciência. Vá pro diabo que te carregue. Tenho um monte de coisas pra conquistar e não quero te ver por perto. Vá pro raio que o parta.

Link da amostra 6

Pelo que vemos nessas amostras, há sutis diferenças na voz impositiva de destrato. Em 4, o falante revela certa descortesia para com o(a) ouvinte, o que se mostra, principalmente, nos construtos cai fora, sai da minha vida e vai embora, todos eles com verbo no imperativo. Entretanto, dificilmente se poderia dizer que esses atos de fala diretivos equivalem a ofensa verbal. Em 5, podemos perceber um tom mais pesado no tratamento com o interlocutor por meio dos imperativos Vá plantar batatas e Vá costurar em outra freguesia. Diferentemente do que vemos em 4, essas expressões deixam entrever uma interlocução não consensual entre os parceiros de interação e assinalam uma atitude mais grosseira em relação ao interlocutor. Já em 6, o "clima” não parece nada amistoso, e o falante, aparentando irritação, destrata seu ouvinte de modo agressivo, conforme demonstram os construtos de comando Vá pro diabo que te carregue e Vá pro raio que o parta. O maior grau de animosidade em 6 por parte do falante pode ser visto nas expressões que demonstram "prejuízo" para o interlocutor: diabo que te carregue e raio que o parta.

Com base nessas amostras, podemos afirmar que a CID indicia um continuum entre menor e maior graus na expressão (inter)subjetiva de descontentamento do locutor e de destrato a seu interlocutor. Também ainda é possível perceber que a voz imperativa de destrato parece tender a ser encabeçada pelo verbo ir (vai embora, Vá plantar batatas, Vá costurar em outra freguesia, Vá pro diabo que te carregue, Vá pro raio que o parta). É, portanto, essa formação específica da CID que nos interessa examinar agora um pouco mais detidamente. 
Iniciemos retomando o primeiro objetivo deste trabalho: descrever os padrões construcionais da CID no que se refere a seus aspectos morfossintáticos, ou seja, o polo da forma, segundo Croft (2001). Para tanto, vejamos as ocorrências a seguir:

7. Vá pras cucuias, vá pra pqp! E se vier me perguntar eu mando esquecer...

Link da amostra 7

8. "Menino, vá pro quinto dos infernos!" Era a exclamação raivosa de uma figura folclórica, fraco do juízo, mas que não admitia ser chamados de "Zé doidinho".

Link da amostra 8

9. Em fevereiro de1982, já na Presidência, recebeu um telegrama do presidente da Associação de Docentes da Unicamp, Eliezer Rizzo de Oliveira, protestando contra a expulsão do professor Reinaldo Cué, um cubano com nacionalidade americana, da Universidade Federal do Ceará. Figueiredo foi curto e grosso: "Vão à merda."

Link da amostra 9

10. A discussão entre os dois aconteceu na área externa na casa após Adrilles dizer que a professora era uma opção de voto no paredão. "Vai te danar. No meu juízo, você é cínico e fingido. Você é um leva e traz. Fica ciscando nos quartos", disse a professora. (https://noticias.bol.uol.com.br/fotos/ bbb15/2015/02/02/segunda-feira-2fev2015---14-dia-do-bbb15.htm?mobile\&imagem $=1$ ).

Link da amostra 10

11. Paula ficou irritada e disse: "Não foi, não. Você sabe como é difícil tirar creme do cabelo? Não dá para tirar sem água. Tomei banho em dupla com a Hary para poder gastar menos. Vai se ferrar, Maycon”.

Link da amostra 11

12. Não bastava o erro ao confundir o filósofo Engels (aquele que escreveu o "Manifesto Comunista" com Karl Marx) por "Hegel”, cometido na denúncia em que pedia a prisão preventiva do ex-presidente Lula, o promotor José 
Carlos Blat, do Ministério Público de São Paulo, ainda respondeu às piadas de forma rude: "Vão caçar o que fazer. Vão catar coquinho".

Link da amostra 12

13. Vai, vai, vai...

Vai ver se eu tô na esquina

Larga do meu pé, jacaré

Sai pra lá, não me azucrina.

Link da amostra 13

Observando-se os aspectos formais da CID nos exemplares de 7 a 13, podemos constatar que essa construção se configura, em termos sintáticos, pela presença do verbo ir (elemento constante) e um termo subsequente. Esse termo pode ser: no primeiro tipo, um sintagma preposicional (SP); no segundo, um verbo precedido de pronome oblíquo "reflexivo" (Pro V), este parecendo um "complemento"; no terceiro, uma oração - aparentemente, "transitiva direta" - com verbo e complemento ${ }^{8}$ (V Comp). Portanto, em suas três formações gerais, a CID com ir pode ser representada, grosso modo, pelos seguintes subesquemas: [Ir SP], [Ir Pro V] e [Ir V Comp].

$\mathrm{Na}$ formação [Ir SP], o SP com para (na verdade, sua variante abreviada pr-Art Def) é o uso predominante, conforme se encontram nas ocorrências em 7 (pras cucuias e pra $p q p$ ) e 8 (pro quinto dos infernos) - além dos casos expressos no excerto 6, apresentado anteriormente, e dos demais existentes nos recortes textuais coletados. Apenas em 9, o falante recorreu à preposição $a(\underline{a} m e r d a)$ - aliás, a única ocorrência com $a$ nas amostras coletadas, que é, nesse caso, de uso pouco comum. A preferência por para se dá, possivelmente, em razão de seu sentido básico de destinação e de sua relação convencional com o verbo ir, que indica deslocamento.

Quanto à configuração [Ir Pro V], observamos, pelas amostras 10 e 11, que o verbo ir é seguido por outro verbo, no infinitivo impessoal, ao qual se antepõe um pronome oblíquo (te danar, em 10, e se ferrar, em 11). Esse pronome parece ser um "complemento" do verbo com que se relaciona, na condição de "objeto direto"; entretanto, não é assim que o entendemos. Defendemos que este é parte integrante do conjunto Pro V, com valor pretensamente "reflexivo". Essa compreensão se baseia no fato de que interpretamos o

\footnotetext{
${ }^{8}$ Optamos pelo termo "complemento" por ser de sentido mais geral, recobrindo tanto o plano semântico (os variados tipos de complementação verbal) quanto o sintático, uma vez que pode ser expresso por categorias variadas $(\mathrm{SN}, \mathrm{SP}$, Oração - Or).
} 
pronome tão somente como forma referencial para indicar/enfatizar sobre quem recai o conteúdo ofensivo expresso pelo verbo, no caso, o(s) ouvinte(s)/leitor(es). Logo, não se trata de uma ação que o(s) interlocutor(es) vai(vão) realizar contra si mesmo(s), o que nos leva a tomar os verbos desses exemplares como pseudotransitivos, aproximando-os dos intransitivos.

No tocante ao design sintático [Ir V Comp], vemos, pelas amostras 12 e 13, que a CID se molda pelo emprego de ir acompanhado de uma oração iniciada por verbo também no infinitivo impessoal (caçar o que fazer e catar coquinho, em 12, e ver se eu tô na esquina, em 13). Ainda considerando a estrutura sintática dessas expressões de forma mais minuciosa, notamos que os respectivos verbos que as encabeçam (caçar, catar e ver) são transitivos diretos, seguidos de um SN/termo equivalente (coquinho e $o$ com a oração relativa encaixada que fazer, em 12) ou de uma oração subordinada ( se eu tô na esquina, em 13), que funcionam como seus respectivos complementos. Contudo, levando em conta que tais estruturas - verbos transitivos diretos e seus respectivos complementos-objetos - não pareiam semanticamente o que expressa sua forma sintática, antes constituindo um todo idiomático de natureza metafórica, assumimos que essas orações em casos assim não são, de fato, transitivas diretas em termos prototípicos (cf. HOPPER; THOMPSON, 1980).

A formulação da CID nessas configurações sintáticas reproduz subesquemas estruturais de comando impositivo com o verbo ir já disponíveis na língua, a saber, ir no imperativo afirmativo de $2^{\text {a }}$ pessoa seguido de um SP indicando destinação locativa ou seguido de orações transitivas diretas (uma delas com pronome oblíquo reflexivo anteposto ao verbo e a outra com verbo e complemento [objeto paciente]). Essas estruturas sintáticas são instanciações da construção de ordem literal com ir, por meio da qual o falante impõe algo para que o interlocutor execute.

Em relação aos aspectos morfológicos da CID, verificamos que existe certa variabilidade nos componentes que a codificam, tal como apontam as ocorrências de 7 a 13 . Essa variabilidade diz respeito, particularmente, aos usos do verbo ir no singular, da preposição para nos casos com SP e do pronome oblíquo no singular nos casos Pro V.

Primeiramente, cabe observar o verbo ir, que é utilizado sempre no imperativo afirmativo. Conforme o que se mostra nos construtos identificados no corpus, esse verbo se limita à referência da segunda pessoa do singular, alternando-se entre as formas vá (em 7 e 8 ) e vai (em 10, 11 e 13), ou da segunda do plural, unicamente expressa por $v a \tilde{a} o^{9}$ (em 9 e 12). Vá associa-se a você, vai a tu e vão a vocês. Segundo Cardoso (2006), a forma

\footnotetext{
9 A forma canônica ide, de $2^{a}$ pessoa do plural, não é utilizada na CID.
} 
vá representa o "imperativo substituto", enquanto a forma vai, o "imperativo verdadeiro". Ainda conforme a autora, essa variação é de natureza social, em se tratando do português europeu, e regional, no caso do português brasileiro.

No que respeita ao uso da preposição na CID com formato [Ir SP], vimos que ela apresenta a forma variante de para, isto é, a abreviação pr-, aglutinada com um artigo definido, que se flexiona em gênero e número, concordando com a palavra (nome) seguinte. Isso se comprova, por exemplo, pelas ocorrências em 7 (pras cucuias, pra pqp [puta que pariu]), e em 8 (pro quinto dos infernos). Além dessas formas, há o emprego da preposição $a$, a qual, ao que tudo indica, parece restrita à expressão à merda - conforme o registro em 9 -, uma vez que não foi identificada relação sua com nenhuma outra palavra.

No que se refere ao emprego do pronome oblíquo na CID com a estrutura [Ir Pro V], ele também se aplica à segunda pessoa, variando entre te e se para o singular (amostras 10 e 11, respectivamente) e apenas se para o plural, como nesta ocorrência: "Agora todo mundo lamenta? Vão se foder!, diz Regis Tadeu." (https://whiplash.net/materias/ news_800/228124-drsin.html). Quanto à variação das formas do singular te/se, vale frisar que ambas são utilizadas muitas vezes indistintamente, alternando-se na relação morfossintática com a forma verbal singular vai, como se apresentam em 10 (Vai te...) e em 11 (Vai se ... $)^{10}$. Já com a forma vá, parece haver restrição para a combinação com te, admitindo apenas o uso de se. Eis uma amostra: "Vá se lascar, seu nego safado, não conte comigo..." (https://www.cifraclub.com.br/ atelier-do-samba/va-se-lascar/letra/).

No plano fonético-fonológico, embora não tenhamos dados acústicos de fala real, sabemos, pela própria vivência social como falantes, que a CID se caracteriza pela expressão sonora em que o locutor levanta a voz em um tom mais alto e ríspido, de modo exclamativo, manifestando aborrecimento e descortesia com seu interlocutor. Tanto é que, na escrita, tal forma de expressão vem, em certas ocorrências, sinalizada pelo ponto de exclamação, indiciando esse traço prosódico oral, como ilustram os casos 14 e 15:

14. E é por esse povo que me permito dizer: "Presidente, vá se danar!"

Link da amostra 14

15. Dias atrás, presenciei uma discussão que, pelo tanto de batatas plantadas, daria para alimentar toda a população do país. Os dois contendores discutiam

\footnotetext{
10 Um estudo específico, possivelmente, poderá oferecer-nos uma explicação plausível para as motivações subjacentes a essa variação, o que não é tarefa deste trabalho. Por enquanto, remetemos a Yacovenco e Scardua (2017).
} 
por causa de uma vaga na rua, motivo mais do que comum nos dias de hoje, em razão do aumento excessivo de veículos nas grandes cidades.

- Vá plantar batatas! - dizia um deles.

- Vá plantar batatas, você! - dizia o outro.

Link da amostra 15

Ainda considerando a elocução fonético-fonológica da CID, chama-nos a atenção o fato de a preposição para apresentar-se sempre na forma reduzida pr- (como nas amostras 7, pra pqp!, e 8, pro quinto), mesmo na modalidade escrita. Pensamos que essa tendência se deve em razão de essa construção ter sua origem na oralidade, em situações tensas, nas quais o locutor manifesta destempero emocional e baixo monitoramento do registro formal/polido.

Retomemos aqui nosso segundo objetivo: analisar a CID em termos de seus graus de esquematicidade, produtividade e composicionalidade.

Em relação à esquematicidade, baseando-nos em Traugott e Trousdale (2013), entendemos que a CID é uma instância subesquemática - $[\mathrm{VY}]_{\text {DESTRATO }}$ - do esquema $[[\mathrm{V}]$ $([\mathrm{Y}])]_{\text {IMPOSIÇÃo }}$ Além da CID, este sanciona construções que representam atos de fala como ordem, ameaça ou proibição, sendo, por sua vez, uma das instanciações da construção de comando. Esta constitui o esquema superordenado mais geral $\left[[\mathrm{X}]_{\text {Dir }}([\mathrm{Y}])\right]$ COMANDo ${ }^{11}$, inseminador dos atos de fala diretivos (ordens, proibições, pedidos, instruções, convites, sugestões e afins, conforme Searle (1984).

A esquematicidade da CID reside no fato de ela representar um modelo paradigmático que sanciona subesquemas construcionais relativamente produtivos, os quais, por seu turno, sancionam certa variedade de types microconstrucionais. Entre esses subesquemas, estão os do tipo com o verbo ir - [Ir Y] -, discutidos neste trabalho, bem como o que se instancia por outros verbos que exprimem xingamento, seguindo o padrão [V-Pro $]^{12}$, a exemplo de Dane-se!.

Essa constatação nos leva à outra propriedade envolvida na CID, qual seja, sua produtividade. Para Traugott e Trousdale (2013), a produtividade de uma construção se revela no fato de esta poder inseminar uma certa quantidade de (micro)construções/(sub) types.

${ }^{11} \mathrm{O}$ "Y" entre parênteses no esquema - $([\mathrm{Y}])$ - significa a não obrigatoriedade de realização desse componente na construção.

12 A microconstrução [V-Pro] não pertence ao escopo deste trabalho. 
De acordo com o que já foi visto em amostragens anteriores, o subesquema [Ir Y] sanciona três diferentes subesquemas de nível inferior relativamente mais especificados: [Ir SP], [Ir Pro V] e [Ir V Comp]. Esses subesquemas possuem graus de produtividade diferenciados, exibindo, cada um deles, um naipe de microconstruções de destrato relativamente fixas/convencionalizadas representativas de cada subtipo. O quadro que segue esboça nossa visão sobre a rede esquemática (parcial) da CI, incluindo a que é o objeto deste estudo.

Quadro 3 - Rede da construção impositiva. ${ }^{13}$

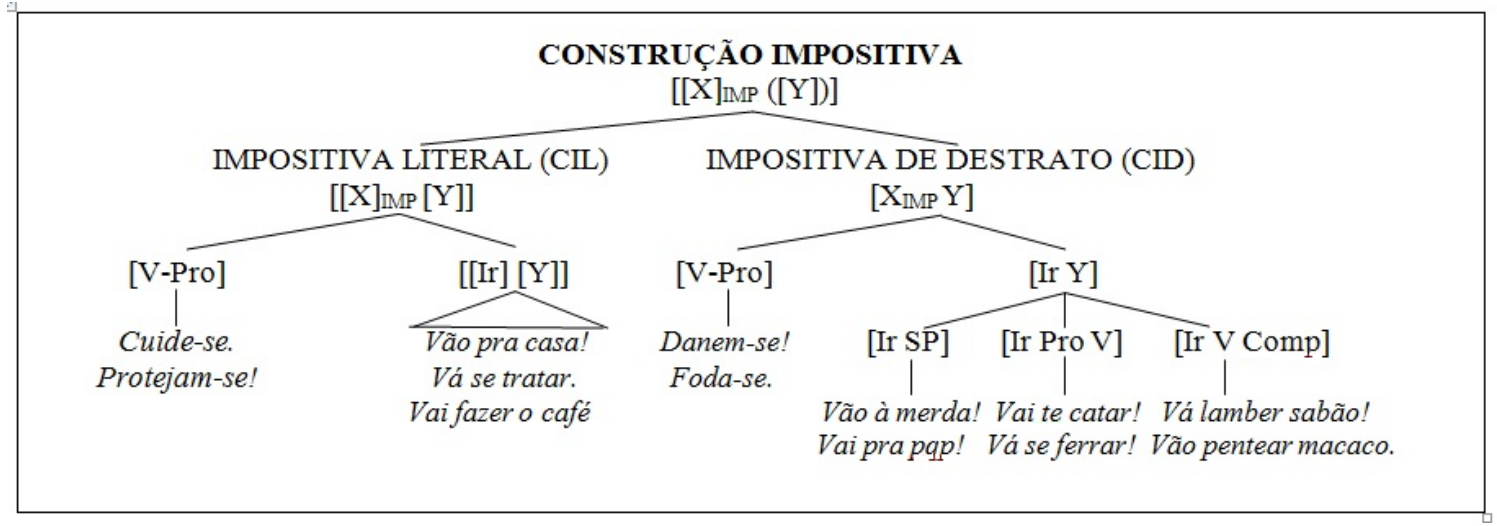

Fonte: Autoria própria.

Pelo que esse quadro nos apresenta, notamos que existe um paralelismo (sub)esquemático entre a CIL e a CID, tanto nas que são encabeçadas pelo verbo ir quanto as que se formatam como V-Pro. Esse paralelismo indicia, a nosso ver, a possível analogia processada na formação da segunda (CID) a partir de bases semântica e formal da primeira (CIL).

Em se tratando da composicionalidade, a CID parece ser não composicional. Em outras palavras, não há paridade entre sua expressão formal e seu significado, sendo o grau de analisabilidade de seus componentes praticamente nulo. Vejamos as seguintes ocorrências:

16. Já que você reclama de tudo, faz o seguinte, vá pra casa do caralho e se lá ainda não estiver bom pra você, vá pros quinto dos infernos.

\footnotetext{
${ }^{13}$ Nessa rede, embora previstas, não estão representadas as construções de comando indireto a exemplo de Poderia me dizer que horas são?
} 
17. "Vai te lascar, ô filho de uma égua", diz eleitor de Bolsonaro, que mora nos EUA, decepcionado. (https://urbsmagna.com/2019/03/22/imperdivel-vai-te-lascar-o-filho-de-uma-egua-diz-eleitor-de-bolsonaro-que-mora-nos-eua-decepcionado/).

Link da amostra 17

18. Musa, sinceramente, vai chatear o Camões. Que podem os poetas, diz-me, contra marketeers, aguados humoristas e outros promotores da realidade? (https://joaquimalexandrerodrigues.blogspot.com/2017/06/musa-sinceramente-vai-chatear-o-camoes.html).

Link da amostra 18

Essas amostras reforçam o que já analisamos anteriormente: a CID com ir é encabeçada invariavelmente por esse verbo, acrescido de outro termo com o qual parece compor um todo fixo convencionalizado, embora haja, em determinados casos, certa variabilidade morfossintática de alguns dos seus elementos. Assim, em 16, Vá pra casa do caralho e vá pros [sic] quinto dos infernos formam, respectivamente, um único bloco significativo, já consagrado pelo uso em situações de tensão entre os interlocutores. Nessa mesma direção, Vai te lascar, em 17, também parece constituir uma só expressão com significado de ofensa ao ouvinte/leitor. Em 18, vai chatear o Camões revela igualmente um conjunto expressivo integrado sinalizando, do mesmo modo, ataque verbal ao(à) parceiro(a) de interlocução.

Portanto, considerando essa breve análise, defendemos que, apesar de podermos "cindir" a CID nas duas partes que a compõem, tal como se mostra nos três subesquemas microconstrucionais de [Ir Y], parece-nos mais plausível vê-la como não composicional, posto que só pode ser compreendida quando tomada como um todo indivisível. Sendo assim, essa cisão funciona apenas para o exame morfossintático da construção, não para as unidades de seu conteúdo, pois nenhuma de suas partes tem significado individual isoladamente, nem mesmo o verbo $i r$. Vista assim, essa construção consiste em um chunk altamente integrado - na acepção de Bybee (2010) -, no sentido de formar uma sequência sintática convencional cujos componentes se constituem como uma unidade semântica inseparável, associada a um contexto específico de uso, no caso, uma situação comunicativa tensa entre falante/escrevente e ouvinte/leitor. 
Sintetizando o que discutimos sobre as propriedades definidoras da CID abordada aqui, alinhados a Goldberg (2003), Hoffmann e Trousdale (2013), Traugott e Trousdale (2013), Fried (2015), entendemos que essa construção é parcialmente especificada e flexível, visto que apresenta um componente constante, no caso, o verbo ir na $2^{\text {a }}$ pessoa (singular ou plural) do imperativo afirmativo, e um slot (Y) subsequente preenchido por um termo ou por uma oração, que forma com esse verbo um todo não composicional indiciando agressividade/ofensa verbal dirigida ao interlocutor. Esse modelo (Ir Y) se mostra esquemático e produtivo na medida em que sanciona um grupo diversificado de microconstruções funcionalmente similares.

Por fim, consideremos agora o terceiro objetivo, que é o de examinar a CID no tocante a fatores semânticos, discursivos e pragmáticos envolvidos em seu uso.

Em termos semânticos, a CID com ir, de um modo geral, designa uma "ordem" de "afastamento" dada pelo locutor a seu(s) interlocutor(es) de forma indelicada/agressiva, indicando não querer mais o contato com este(s). Nesse sentido, a CID pressupõe uma situação de discórdia entre os sujeitos de interação, na qual o falante/escrevente externa descontentamento com seu(s) interlocutor(es) e o(s) ofende verbalmente, repelindo$-\mathrm{o}(\mathrm{s}) \cdot{ }^{14}$

Ocorre que a CID, conforme atestam todos os exemplares colhidos, verbaliza-se por meio de expressões não literais, cuja voz de comando não descreve, de fato, o conteúdo do que é enunciado. Dito de outro modo, não há correspondência entre o que é codificado e o efeito de sentido desejado, posto que a intenção do locutor é insultar seu interlocutor e encerrar o contato, não propriamente lhe dar uma ordem. Sendo assim, tal construção se afasta, em parte, do ato de fala verdadeiramente impositivo que exprime uma ordem explícita convencional (a construção impositiva literal - CIL). Confrontemos estas amostras a fim de observarmos melhor as distinções entre elas:

19. F2: [...] mulher... vá buscar pastilha Halls ... [...] vá lá...

(FURTADO DA CUNHA, 2011, p. 18).

20. F5: [... vá lá pra tia Rosa... vá morar com ela...

(FURTADO DA CUNHA, 2011, p. 221).

\footnotetext{
14 Distinguimos essa condição prototípica de realização da CID daquela em que o falante, dada a intimidade com o parceiro de interação, utiliza expressões de "destrato" em total descontração, de modo que seu interlocutor não se sente insultado nem interpreta como encerramento do diálogo.
} 
21. "Vão pro inferno", diz Felipão, interrompendo entrevista de Deyverson. O técnico foi agressivo com jornalistas após polêmica que envolvia o atleta do Palmeiras..

Link da amostra 21

22. “Que dia eu vou operar ela? O dia em que eu quiser! Vá comer merda!”, xingou o médico ao jornalista, em reportagem feita pela TV Anhanguera, afiliada da Globo em Goiás.

Em 19 e 20, os respectivos construtos vá buscar pastilha Halls, vá lá, no primeiro caso, e vá lá pra tia Rosa, vá morar com ela, no segundo, expressam uma voz impositiva literal e mais direta, designando sentidos mais referenciais: o locutor é impelido a se deslocar (sinalizado pelo verbo ir) para algum lugar (vá lá, em 19, e vá lá pra tia Rosa, em 20) e fazer algo (buscar pastilha, em 19, e morar com ela, em 20). Já em 21 e 22, Vão pro inferno e Vá comer merda, respectivamente, não carregam o mesmo valor impositivo referencial de se dirigir a um certo local para fazer algo. Em outras palavras, o significado em 21 não é uma ordem para se mover (Vão) de um ponto a outro (pro inferno) e em 22 também não é uma ordem para se deslocar (Vá) a fim de realizar uma tarefa (comer merda). Na verdade, os casos 21 e 22 representam impropérios injuriosos proferidos pelos falantes contra seus ouvintes. Tanto é que o conteúdo das expressões após o verbo ir, em casos como esses, é sempre de valor negativo, variando apenas em grau de agressividade e de ofensa ao interlocutor.

Dado o que se encontra nas amostras em 21 e 22, defendemos que a CID representa um caso de extensão semântica da construção impositiva mais básica/referencial com o verbo ir (que significa a realização futura de uma ação a partir de um comando). Sob esse viés, podemos considerar a CID uma instanciação da construção impositiva de ordem literal mediante o link de herança metafórica. Para Goldberg (1995), Boas (2013), Traugott e Trousdale (2013), esse tipo de link se mostra no caso de um ou mais componentes de uma construção corresponder(em) a mapeamento(s) metafórico(s) do(s) de outra construção com significado(s) mais básico(s) e estrutura similar.

Quanto à CID, entendemos que o link de herança metafórica reside no fato de o chunk de insulto com o verbo ir no imperativo, em vez de designar deslocamento obriga- 
tório para certo lugar/realizar alguma ação, codifica, em termos metafóricos, o distanciamento afetivo e comunicativo "ordenado" ao ouvinte/ leitor, como se este, na verdade, tivesse de "ir a algum lugar" /ir fazer algo". Nesse sentido, a CID instancia a metáfora DISTANCIAMENTO AFETIVO É DISTANCIAMENTO ESPACIAL. Em sendo assim, enunciados como em 21 (Vão pro inferno) e em 22 (Vá comer merda!) resultam na "atenuação" da voz impositiva, uma vez que, por entendê-la como um insulto e rompimento do diálogo, e não como uma ordem em sentido literal, o interlocutor não está pragmaticamente comprometido com a "realização" do "comando".

Da mesma forma, confrontando-se, ainda, o construto Vai te lascar (em 17) com "Vá se lavar"15, por exemplo, percebemos que, enquanto este se refere a uma ordem que implica ter de se movimentar até um certo local (Vá) para realizar uma ação reflexiva (se lavar), aquele não remete a esse mesmo significado básico. Em vez de ordem direta de deslocamento físico, o interlocutor interpreta como xingamento e repulsa por parte do locutor, em razão do dissenso estabelecido entre eles. Quer dizer, as correspondências entre forma e conteúdo verificadas em casos como 19, 20 e este último não são possíveis em casos como os existentes em 17, 21 e 22. Assim, as ocorrências 19, 20 e Vá se lavar, além de referenciais, são composicionais e analisáveis; 17, 20 e 21, por seu turno, não exibem essas mesmas propriedades; antes formam, per se, um chunk não analisável, tal como entendido por Bybee (2010), de significado metafórico, que não resulta da soma de suas partes.

A relação metafórica entre a CID com ir e a construção de comando que designa ordem literal/direta se constrói via analogização. Ou seja, uma construção é utilizada com base na similitude de forma e de "conteúdo" com uma construção mais básica já existente (TRAUGOTT; DASHER, 2002; BYBEE, 2010; TRAUGOTT; TROUSDALE, 2013). No caso da CID, o pareamento forma-função é formulado em termos da construção de comando literal (CIL) com ir, com a qual aquela mantém paralelismo analógico, especialmente no plano estrutural, conforme já demonstrado no Quadro 3.

O processo de analogização ocorrido entre a CID e a construção fonte pode ser visto, ainda, como um fenômeno de motivação icônica, no sentido de que a primeira representa uma tentativa de "reprodução" esquemática da segunda, que lhe serve de base, dadas as similaridades entre ambas. Entretanto a CID deve ser tomada como um caso de "iconicidade fraca", nos termos de Beck (2000). Segundo esse autor, essa forma de iconicidade diz respeito ao fato de não haver correspondência/transparência entre o con-

$\overline{15}$ https://pt-br.facebook.com/DCEdaUSP/posts/741117282632877. 
teúdo e a forma que o codifica. Assim, uma construção cujo significado é metafórico, não composicional, é, portanto, menos icônica ou mesmo não icônica se comparada a outra com maior correlação entre forma e significado à qual se assemelha. Sendo assim, a construção iconicamente fraca - no caso aqui, a CID - deverá ser considerada mais marcada em razão de sua complexidade cognitiva (por ser não "literal”) e por sua provável baixa frequência/produtividade.

Para Traugott e Trousdale (2013), o uso inovador de uma construção consiste numa espécie de desvio ("mismatch") do significado central da construção existente, ocorrendo sancionamento parcial desta. Ainda conforme esses autores, nesse contexto, o falante/escrevente recorre a uma implicatura, enquanto o ouvinte/leitor colabora mediante inferência pragmática para a construção do sentido. Nessa perspectiva, portanto, a construção em tela - que verbaliza insulto ao interlocutor, indicando o "afastamento" deste/interrupção do diálogo por meio de uma expressão de comando ofensiva do tipo "ir para algum lugar" ou "ir fazer algo" - é conceitualizada em termos análogos aos da construção convencional impositiva com ir sem, contudo, manter o paralelo semântico com esta. Também não há paralelo pragmático entre uma construção e outra, visto que, no caso da CID, o interlocutor não interpreta a voz de comando como verdadeiramente uma ordem que tem de ser literalmente cumprida.

Concentrando-nos mais especificamente nos aspectos discursivos e pragmáticos da CID, entendemos que esta pode ser identificada como uma espécie de ponto limítrofe entre o plano das relações intratextuais/endofóricas, associado à progressão textual-discursiva, e o plano da relação intersubjetiva (extratextual/exofórica), do âmbito da pragmática. Esse entendimento decorre da observação de que, por um lado, tal construção estabelece certo vínculo com determinado conteúdo informacional do texto e, por outro, projeta-se sobre o interlocutor.

Cabe ressaltar, ainda, que a CID é de natureza inerentemente responsiva, no sentido de consistir em uma reação contra o outro. Sendo assim, ao mesmo tempo em que remete a alguma atitude ou declaração por parte do interlocutor, explicitada no cotexto, da qual o locutor discorda e/ou pela qual se sente ofendido, ela também expressa o revide deste àquele por meio do ataque verbal, indiciando o clima de tensão e de desacordo entre ambos. Atentemos para os seguintes casos:

23. A partir daí, o tom da discussão ficou ainda mais quente. Lindbergh acusou os colegas tucanos de "fascistas" e ouviu de Aloysio Nunes (PSDB-SP): "Vocês 
são um bando de fanáticos". Irritado, Cassio Cunha Lima gritou, fora do microfone, mas para quem quisesse ouvir: "Vai pra puta que o pariu", em resposta ao colega petista.

Link da amostra 23

24. Uma semana e meia atrás, quando ele rebateu uma crítica que o atacante Ronaldo fez ao jornalismo da Band, entre bobalhão, baleia, trouxa e outros elogios, furibundo, ele lascou 13 "vai te catar" em meio a uma chuva de perdigotos. "Ronaldo, vai te catar, velho!"

Link da amostra 24

25. O comentarista [Reinaldo Azevedo] disse ser contra três das 10 medidas do pacote apresentado pelo Ministério Público contra a corrupção. "Vai plantar batata, cara. Vem aqui me dizer que coleta ilegal de prova é coisa de democracia...”

Link da amostra 25

Podemos ver, nesses excertos, que as instanciações da CID não têm vínculo sintático direto com outra oração nos respectivos contextos linguísticos em que se encontram; ou seja, constituem, cada uma, enunciados em certa medida "desgarrados" (ou uma construção à parte, relativamente independente). Todavia se relacionam com algum conteúdo informacional (antecedente ou posterior) do texto, sendo, nesse sentido, relativamente dependentes. Em 23, Vai pra puta que o pariu é complemento oracional de gritou e estabelece vínculo cotextual com as informações sobre a acusação de Lindbergh [Farias] e a consequente irritação de Cássio Cunha Lima, que proferiu o impropério. Na mesma direção, vai te catar, em 24, associa-se cotextualmente à informação precedente sobre o rebate feito pelo jornalista Datena à crítica do jogador Ronaldo. Em 25, Vai plantar batata liga-se à informação seguinte, revelando o aborrecimento e a reprovação do comentarista Reinaldo Azevedo quanto à afirmação feita pelo juiz Sérgio Moro. Assim, embora seja um enunciado situado na borda sintática (à esquerda ou à direita) de um dado segmento conteudístico, mantém com este um link intratextual e discursivo coerente, justificando sua participação e seu nexo na teia multiproposicional (cf. GIVÓN, 1998).

Quanto à vinculação extratextual da CID, é inequívoco que ela se volta para o interlocutor, o que é abertamente atestado nessas (e nas demais) amostras, em especial, 
pela referência direta à $2^{\text {a }}$ pessoa do discurso. Por elas, o falante/escrevente dirige um insulto de forma impositiva ao seu ouvinte/leitor, assinalando desentendimento entre eles e "exigindo" o "distanciamento" deste. Dessa forma, essa construção deixa à mostra seu caráter predominantemente intersubjetivo, que é do domínio pragmático. O quadro seguinte esboça, grosso modo, as diferenças entre a construção impositiva de ordem direta e a de destrato, sintetizando parcialmente o que foi examinado até aqui quanto aos planos sintático, semântico, discursivo e pragmático referentes à CID:

Quadro 4 - Resumo comparativo da construção impositiva com ir.

\begin{tabular}{|c|c|c|c|c|c|c|}
\hline \multicolumn{7}{|c|}{ CONSTRUÇÃO IMPOSITIVA COM IR } \\
\hline & \multicolumn{3}{|c|}{ Ordem Direta/Literal } & \multicolumn{3}{|c|}{ Destrato } \\
\hline \multirow[t]{2}{*}{ Sint. } & [[Ir] [SP]] & [[Ir] [Pro V]] & [[Ir] [V Comp]] & [Ir SP] & [Ir Pro V] & [Ir V Comp] \\
\hline & \multicolumn{3}{|c|}{ Chunks composicionais e analisáveis } & \multicolumn{3}{|c|}{ Chunks não composicionais e não analisáveis } \\
\hline \multirow[t]{2}{*}{ Sem. } & Dirigir-se a algum lugar & \multicolumn{2}{|c|}{ Deslocar-se (para) fazer algo } & \multirow{2}{*}{\multicolumn{3}{|c|}{$\begin{array}{c}\text { Ofensa e repulsa ao interlocutor } \\
\text { Sentidos mais abstratizados (metafóricos) }\end{array}$}} \\
\hline & \multicolumn{3}{|c|}{ Sentidos mais ancorados na concretude } & & & \\
\hline Disc. & \multicolumn{3}{|c|}{ Não responsiva, independente de co(n)texto discursivo } & \multicolumn{3}{|c|}{ Responsiva, dependente de co(n)texto discursivo } \\
\hline Prag. & $\begin{array}{l}\text { A ordem comprom } \\
\text {-impolidez }\end{array}$ & $\begin{array}{l}\text { te o interlocut } \\
\text { menor dano à }\end{array}$ & $\begin{array}{l}\text { tor a realizá-la } \\
\text { s faces }\end{array}$ & \multicolumn{3}{|c|}{$\begin{array}{c}\text { O interlocutor é repelido, mas não obrigado a nada } \\
\text { +impolidez e maior dano às faces }\end{array}$} \\
\hline Ex.: & Vá para casa. & Vá se lavar. & Vá pegar pastilha. & Vão pro inferno. & Vai te danar! & Vá comer merda. \\
\hline
\end{tabular}

Fonte: Autoria própria.

Ainda dentro do terreno da relação locutor-interlocutor, em razão do desacordo interpessoal, a CID assinala o rompimento da polidez e a desconstrução da face positiva. Nesse sentido, ela expressa um ato de fala que colide com a boa relação social - a qual, normalmente, deve(ria) haver entre os parceiros de interlocução -, revelando quebra de conduta/contrato nessa relação (LEECH, 1983). Ao recorrer a esse tipo de construção, o locutor abre mão do resguardo à face (sua e do outro), desprezando a censura social em favor da própria liberdade de ação/expressão. Agindo assim, acaba por causar danos à autoimagem e à de seu(s) interlocutor(es).

As amostras de 23 a 25 (além das apresentadas anteriormente) deixam claro que, nessas circunstâncias, parece mesmo não haver preocupação com o resguardo da imagem pública - nem do próprio locutor e menos ainda de seu interlocutor. Isso porque, com o insulto, o falante/escrevente se expõe inapropriadamente, demonstrando descontrole emocional e descortesia, bem como afeta negativamente o outro. 
Contudo, de acordo com Reis (2009), Cunha e Silveira (2011), Barrere (2017), por exemplo, a atitude de preservação da face e as estratégias de polidez devem ser entendidas num continuum, que vai do polo positivo ao negativo. Assumindo esse viés, vemos, nas amostras citadas, que elas se apresentam gradientemente desde as menos rudes até as mais grosseiras e ofensivas ao interlocutor. Assim, comparando-se as ocorrências em 24 (vai te catar) e 25 (Vai plantar batata) com a que se encontra em 23 (Vai pra puta que o pariu), somos levados a admitir que aquelas revelam um grau de destrato inferior a esta última. Vejamos mais as ocorrências que seguem:

26. F2: $[\ldots]$ ficar contando faltinha... vai pra lá ômi...

(FURTADO DA CUNHA, 2011, p. 63).

27. O motorista do "meu" táxi gritou para o infrator:

- Ei amigo, sua carteira está vencida!

Ao que o meliante respondeu, enquanto tentava passar entre dois carros:

- Vá pentear macacos!

Link da amostra 27

28. Vai tomar no cu. Quem falou que aquela imagem é Deus?”

Link da amostra 28

É facilmente perceptível, por essas amostras, que o grau de impolidez/agressividade e de comprometimento das faces é bem menor na expressão Vai pra lá, em 26, do que o verificado na um tanto hostil Vá pentear macacos!, em 27, e na mais ofensiva ainda Vai tomar no cu, em 28. Esses e os demais casos reforçam, portanto, o entendimento de que há, de fato, uma escalaridade na demonstração de destrato e de ameaça à face.

Vista pelo ângulo do desencontro entre os interagentes comunicativos, a CID parece abrigar uma contradição: por um lado, aponta para o princípio de cooperação, no sentido de os sujeitos de interlocução estarem conjuntamente engajados na construção de significado(s), conforme postula Grice (1982); por outro, marca o travamento discursivo, revelando o desejo do locutor em, de maneira inesperada e rude, encerrar o contato e "distanciar" o outro (CULPEPER, 2012). 


\section{Palavras (quase) finais}

Neste trabalho, traçamos como objetivos considerar a Construção Impositiva de Destrato com o verbo ir - CID - atentando para os planos da forma e da função. No que se refere à configuração geral, vimos que essa construção se caracteriza esquematicamente por meio da estrutura [Ir Y], na qual Ir, no imperativo afirmativo de $2^{\text {a }}$ pessoa (singular ou plural), é o componente constante e $Y$ constitui o slot a ser preenchido. Nesse sentido, a CID é uma construção parcialmente especificada e flexível.

Esse esquema é relativamente produtivo na medida em que pode sancionar um grupo de subesquemas microconstrucionais, os quais são identificados pelas formas sintáticas [Ir SP], [Ir Pro V] ou [Ir V Comp]. Tais microconstruções podem ser instanciadas, respectivamente, por types como, por exemplo, Vão pras cucuias, Vai te catar, Vá pentear macaco. Expressões como essas, entre muitas outras do tipo, já são, de certo modo, convencionalizadas pelo uso, havendo pouca variação em alguns de seus componentes internos.

Do ponto de vista semântico, a CID conceitualiza a manifestação de insulto, em que o locutor, por se sentir contrariado/importunado pelo interlocutor "ordena" o "afastamento" deste de maneira ofensiva. Nesses termos, o conteúdo semântico dessa construção é incompatível com o que é expresso por sua configuração léxico-sintática, visto que, ao enunciar "Vá pra X" ou "Vá fazer X”, de modo ríspido e hostil, o falante/escrevente não está dando mesmo uma ordem em sentido literal para que o interlocutor a cumpra de fato. Está, em vez disso, sinalizando sua contrariedade e "impondo", agressivamente, o "distanciamento" do outro. Assim constituída, a CID representa extensão semântica da construção mais básica de ordem literal direta, assinalando, com isso, o link de relação metafórica entre esta e aquela de sentido mais abstrato. Ou seja, em sua formulação, a CID é conceitualizada em termos da construção de comando real com ir, o que se dá pelo processo de analogização. Nesse caso, embora ambas as construções revelem certas semelhanças estruturais, não compartilham as mesmas correspondências funcionais (de significado e de fins pragmáticos). Dadas essas condições, a CID deve ser considerada como menos icônica e mais marcada em comparação com a construção mais básica que lhe serve de modelo.

Considerando a participação da CID no discurso, como esta é de natureza eminentemente responsiva, uma vez que expressa uma "resposta" agressiva do locutor a algo feito/dito pelo interlocutor, desagradável para aquele, ela se conecta no texto com a porção relativa à informação do fato motivador dessa "resposta". Desse modo, essa construção raramente apresenta alguma relação sintática interoracional; em vez disso, consiste mais 
num enunciado de fronteira, à direita ou à esquerda do conteúdo principal. Sob esse ponto de vista, a CID constitui-se como uma construção sintaticamente "desgarrada"/"autônoma”, por não ser propriamente um constituinte interoracional, porém dependente do co(n)texto discursivo em que se encontra e ligada a este em alguma medida.

Quanto à dimensão pragmática, constatamos que a CID, dado o seu caráter responsivo, projeta-se sobre o interlocutor, aspecto comprovado, entre outros, pelo emprego do verbo na $2^{\text {a }}$ pessoa do discurso em tom impositivo. Esse fato atesta a função primordialmente dialogal dessa construção.

Outro aspecto pragmático a considerar em relação à CID tem a ver com sua gradiência no que se refere ao comprometimento da face e à manifestação de impolidez. Nesse sentido, vimos, por meio dos exemplares expostos, que essa construção varia, de modo escalar, entre os construtos menos rudes e os mais ofensivos. Em sendo assim, há expressões que, pelo seu grau atenuado de impolidez, implicam menor ameaça às faces dos parceiros de interação; mas há outras que revelam um grau acentuado de descortesia e de agressividade, o que leva a um sério comprometimento da imagem social dos interagentes. Neste último caso, especialmente, o locutor ultrapassa os limites da boa conduta, quebrando o acordo de interlocução tolerante e respeitosa.

\section{Referências}

ANDRADE, M. A. S. Construções gramaticais com ir no português brasileiro contemporâneo. Tese (Doutorado em Linguística) - Programa de Pós-graduação em Estudos da Linguagem, Universidade Federal do Rio Grande do Norte, Natal, 2017.

AUSTIN, J. L. Quando dizer é fazer: palavras e ações. Trad. D. M. de Souza Filho. Porto Alegre: Artes Médicas, 1990. (Col. Série Discurso Psicanalítico).

BARRERE, L. L. Face e polidez linguística em reclamações online: uma análise sob o viés pragmático. Entrepalavras, Fortaleza, v. 7, p. 383-405, jan./jun., 2017.

BECK, D. The syntax, semantics, and typology of adjectives in Upper Necaxa Totonac. Linguistic Typology, v. 4, n. 2, 2000.

BECKNER, C. et al. Language is a complex adaptive system: position paper. Language Learning, v. 59. p. 1-26, 2009.

BOAS, H. C. Cognitive Construction Grammar. In: HOFFMANN, T.; TROUSDALE, G. (Eds.). The Oxford handbook of Construction Grammar. New York: OUP, 2013, p. 176188.

BROWN, P.; LEVINSON, S. Politeness: some universals in language usage. Cambridge: CUP, 1987.

BYBEE, J. Language, usage and cognition. Cambridge: CUP, 2010. 
BYBEE, J. Markedness: iconicity, economy, and frequency. In: SONG, J. J. (Ed.). The Oxford Handbook of Linguistic Typology. Oxford: OUP, 2012, p. 131-147.

CARDOSO, D. B. B. O imperativo gramatical no português brasileiro. Estudos Linguísticos, v. 14, n. 2, Belo Horizonte, p. 317-340, jun./dez., 2006.

CEZARIO, M. M.; FURTADO DA CUNHA, M. A. (Orgs). Linguística Centrada no Uso: uma homenagem a Mário Martelotta. Rio de Janeiro: Mauad; FAPERJ, 2013.

CROFT, W. Radical construction grammar: syntactic theory in typological perspective. New York: OUP, 2001.

CULPEPER, J. Politeness and impoliteness. In: ANDERSEN, G.; AIJMER, K. (Eds.). Pragmatics of society. Berlin: Mouton de Gruyter, 2012, p. 393-438. (Col. Handbooks of Pragmatics, 5).

CUNHA, T. F.; SILVEIRA, S. B. Estratégias de im-polidez em situações de conflito. Discurso \& Sociedad, v. 5, n. 4, p. 677-700, 2011.

DIESSEL, H. Usage-Based Linguistics. In: ARONOFF, M. (Ed.). Oxford Research Encyclopedia of Linguistics. New York: OUP, 2017.

FORD, C.E.; FOX,B.THOMPSON, S.Social interaction and grammar.In. TOMASELLO, M. (Ed.). The new psychology of language: cognitive and functional approaches to language structure. v. 2, Mahwah, NJ: Lawrence Erlbaum, 2003, p. 119-144.

FRIED, M. Construction grammar. In: KISS, T.; ALEXIADOU, A. (Eds.). Syntax theory and analysis: an international handbook, v. 1. Handbooks of Linguistics and Communication Science. Berlin: Mouton de Gruyter, 2015, p. 974-1003.

FURTADO DA CUNHA, M. A. Banco Conversacional de Natal. Natal: EdUFRN, 2011.

FURTADO DA CUNHA, M. A.; BISPO, E. B.; SILVA, J. R. Linguística Funcional Centrada no Uso: conceitos básicos e categorias analíticas. In: CEZARIO, M. M.; FURTADO DA CUNHA, M. A. (Orgs). Linguística Centrada no Uso: uma homenagem a Mário Martelotta. Rio de Janeiro: Mauad; FAPERJ, 2013.

FURTADO DA CUNHA, M. A.; BISPO, E. B.; SILVA, J. R. Variação e mudança em perspectiva construcional. Natal: EdUFRN, 2018.

GIVÓN, T. Functionalism and grammar. Amsterdam; Philadelphia: John Benjamins,1995.

GIVÓN, T. The functional approach to grammar. In: TOMASELLO, M. (Ed.). The new psychology of language: cognitive and functional approaches to language structure. Mahwah, NJ: Lawrence Erlbaum, 1998, p. 41-66.

GOFFMAN, E. A elaboração da face: uma análise dos elementos rituais na interação social. In: FIGUEIRA, S. A. (Org.). Psicanálise e ciências sociais. Rio de Janeiro: Francisco Alves, 1980, p. 76-114.

GOLDBERG, A. E. A construction grammar approach to argument structure. Chicago: The University of Chicago Press, 1995. 
GOLDBERG, A. E. Constructions: a new theoretical approach to language. TRENDS in Cognitive Sciences, v. 7, n. 5, p. 219-224, 2003.

GONÇALVES, A. O processo de gramaticalização do verbo IR no português brasileiro: um estudo diacrônico. Domínios de Lingu@gem - Revista Eletrônica de Linguística, v. 6, n. 1, p. 393-417, $1^{\circ}$ sem., 2012. Disponível em: http://www.seer.ufu.br/index.php/ dominiosdelinguagem. Acesso: 25 fev. 2019.

GRICE, H. P. Lógica e conversação. Trad. J. W. Geraldi. In: DASCAL, M. (Org.). Fundamentos metodológicos da Linguística - Pragmática: problemas, príticas, perspectivas da Linguística, v. IV. Campinas: Ed. do Organizador, 1982, p. 81-103.

HASPELMATH, M. Frequency vs. iconicity in explaining grammatical asymmetries. Cognitive Linguistics, v. 19, n. 1, p. 1-33, 2008.

HOPPER, P. J.; THOMPSON, S. A. Transitivity in grammar and discourse. Language, n. 56, p. 251-299, 1980.

HORN, L.; KECSKES, I. Pragmatics, discourse and cognition. In: ANDERSON, S. et al. (Eds.). The language-cognition interface. Geneva: Droz, 2013, p. 353-373.

KEMMER, S.; BARLOW, M. Introduction: a usage-based conception of language. In: BARLOW, Michael; KEMMER, Suzanne. (Eds.). Usage-based models of language. Stanford: Center for the Study of Language and Information, 2002, p. vii-xxviii.

LAKOFF, R. The limits of politeness: therapeutic and courtroom discourse. Multilingua, v. 8, n. 2/3, p. 101-129, 1989.

LEECH, G. Principles of Pragmatics. London: Longman, 1983.

LONGHIN-THOMAZI, S. R. Vai que eu engravido de novo?: gramaticalização, condicionalidade e subjetivização. Lusorama, v. 81-82, p. 135-150, 2010.

MÓIA, T. Aspetos da gramaticalização de ir como verbo auxiliar temporal. Revista da Associação Portuguesa de Linguística, v. 3, n. 9, p. 213-239, 2017.

OLIVEIRA, J. A. Polidez e identidade: a virtude do simulacro. Biblioteca on-line de ciências da comunicação, 2005. Disponível em: http:/ / www.bocc.ubi.pt/pag/oliveira-jair-polidezidentidade. pdf. Acesso: 20 mar. 2019.

OLIVEIRA, J. M. O imperativo gramatical nas capitais do Nordeste: análise sociolinguística de dados do ALiB. In: LOPES, N. S. da (Orgs.). Estudos sobre o português do Nordeste: língua, lugar e sociedade. São Paulo: Blucher, 2017, p. 27-44.

OLIVEIRA, M. R.; CEZARIO, M. M. Funcionalismo linguístico: diálogos e vertentes. Niterói: EdUFF, 2017.

OLIVEIRA, M. R.; ROSÁRIO, I. C. do (Orgs.). Linguística centrada no uso: teoria e método. Rio de Janeiro: Lamparina; Faperj, 2015.

OLIVEIRA, V. M. Caracterização da polifuncionalidade morfossintática, semântica e discursiva do verbo "ir". Dissertação de Mestrado. Rio de Janeiro: UFRJ, 2009. 
ÖSTMAN, J-O.; FRIED, M. (Eds.). Construction grammars: cognitive grounding and theoretical extensions. Philadelphia: John Benjamins, 2005.

PINHEIRO, R. C. A regência do verbo ir de movimento por falantes cultos de FortalezaCE: relação entre ensino e pesquisa. Linha D’Água (Online), São Paulo, v. 27, n. 1, p. 55-72, jun., 2014. Disponível em: https://www.revistas.usp.br/linhadagua/issue/view/5611. Acesso: 30 mar. 2019.

REIS, R. L. Desculpas púbicas e política. Dissertação (Mestrado em Letras) - Pontifícia Universidade Católica do Rio de Janeiro, Rio de Janeiro, 2009.

RUMEU, M. C. B. Formas variantes do imperativo de segunda pessoa nos séculos XIX e XX: a expressão do social. Signum: Estudos Linguísticos, v. 19, n. 2, Londrina, p. 310-341, dez. 2016.

SAMPAIO, D. A. Modo imperativo: sua manifestação/expressão no português contemporâneo. Dissertação de Mestrado. Salvador: UFBA, 2001.

SCHERRE, M. M. P. Aspectos sincrônicos e diacrônicos do imperativo gramatical no português brasileiro. Alfa, v. 51, n. 1, São Paulo, p. 189-222, 2007.

SEARLE, J. R. Os actos de fala: um ensaio de Filosofia da Linguagem. Trad. C. Vogt. Coimbra: Almedina, 1984. (Col. Novalmedina, 12).

SILVA, J. R. Intensificação do verbo e mudança construcional. Soletras. n. 37, p. 224-245, $1^{\circ}$ sem., 2019.

SOUZA FILHO, D. M. A Teoria dos Atos de Fala como concepção pragmática de linguagem. Filosofia Unisinos, v. 7, n. 3, p. 217-230, set./dez., 2006.

TOMASELLO, M. Constructing a language: a usage-based theory of language acquisition. Cambridge: Harvard University Press, 2003.

TRAUGOTT, E. C.; DASHER, R. B. Regularity in semantic change. Cambridge: CUP, 2002.

TRAUGOTT, E. C.; TROUSDALE, G. Constructionalization and constructional changes. New York: OUP, 2013.

WIEDEMER, M. L. A regência variável do verbo "ir" de movimento na fala de santa Catarina. Dissertação de Mestrado em Linguística. Florianópolis: UFSC, 2008.

WIEDEMER, M. L.; OLIVEIRA, M. R. (Orgs.). Novos encaminhamentos teóricometodológicos da Linguística Funcional Centrada no Uso. Soletras, n. 37, 1º sem., 2019.

YACOVENCO, L. C.; SCARDUA, J. R. A variação pronominal de segunda pessoa: contribuições da sociolinguística para o ensino de língua portuguesa. Working Papers em Linguística, v. 18, n. 2, p. 171-191, Florianópolis: UFSC, ago./dez., 2017. 